\title{
Electric Vehicles for Improved Operation of Power Systems with High Wind Power Penetration
}

\author{
Larsen, Esben; Chandrashekhara, Divya K; Østergaard, Jacob
}

Published in:

IEEE Energy 2030 Conference, 2008. ENERGY 2008.

Link to article, DOI:

10.1109/ENERGY.2008.4781053

Publication date:

2008

Document Version

Publisher's PDF, also known as Version of record

Link back to DTU Orbit

Citation (APA):

Larsen, E., Chandrashekhara, D. K., \& Østergaard, J. (2008). Electric Vehicles for Improved Operation of Power Systems with High Wind Power Penetration. In IEEE Energy 2030 Conference, 2008. ENERGY 2008. (pp. 1-6). IEEE. https://doi.org/10.1109/ENERGY.2008.4781053

\section{General rights}

Copyright and moral rights for the publications made accessible in the public portal are retained by the authors and/or other copyright owners and it is a condition of accessing publications that users recognise and abide by the legal requirements associated with these rights.

- Users may download and print one copy of any publication from the public portal for the purpose of private study or research.

- You may not further distribute the material or use it for any profit-making activity or commercial gain

- You may freely distribute the URL identifying the publication in the public portal 


\title{
Electric Vehicles for Improved Operation of Power Systems with High Wind Power Penetration
}

\author{
Esben Larsen, Divya K. Chandrashekhara, Jacob Østergård \\ Technical University of Denmark, Department of Electrical Engineering \\ Elektrovej, DTU Building 325, DK-2800 Kgs. Lyngby
}

\begin{abstract}
In a power system with a high share of wind energy the wind fluctuation causes a variation in the power generation, which must be compensated from other sources. The situation in Denmark with a penetration of more than $20 \%$ wind in yearly average is presented. The introduction of electric drive vehicles (EDV) as flexible loads can improve the system operation. Bidirectional power exchange through batteries (vehicle to grid) can be seen as a storage system in the grid. An analysis of possible economical incentives for the vehicle owners will be shown. By control of EDV charging through a price signal from the day ahead market the economical incentives for an EDV-owner will be small. If the EDV's can participate in the regulation of the grid through ancillary services the incentives will be increased to an attractive level.
\end{abstract}

\section{WIND PENETRATION IN THE DANISH POWER GRID - THE WORLD HIGHEST.}

The Danish power system is unique due to the very high penetration of wind power. In summary the system can be characterised by:

o The wind power technology is very mature in Denmark and the Danish electricity system operates reliably with about $20 \%$ wind power penetration in yearly average.

- During certain hours the wind power exceeds the total consumption within Denmark and this surplus is exported to the neighbouring countries at low price or even in some hours at zero price. In those situations, it happens that the power output of the wind turbines is reduced and some wind turbines are even stopped.

- High prices for regulating/balancing wind power

- Inaccuracies in wind power forecast has caused loss of revenue for wind power producers

○ $50 \%$ of total consumption is from distributed generation

- There is some correlation between the load curve and the wind production (both seasonal-yearly and a few days on a daily basis)

- Some parts of the Danish electricity system are connected only through a single line (e.g. the Bornholm distribution system) and any fault on this line will cause the system to operate in island mode
[1]. In particular, the Bornholm system is connected through an undersea cable. This cable has been cut by the anchors of big ships 2 times in the past 4-5 years and it takes a long time to repair the cable. Consequently it is forced to operate in an island manner and most of the wind turbines are shut down during this period due to the wind power fluctuations

Differences in the social behaviour (driving patterns) between US and Denmark.

o The driving distances in Denmark (40 km on an average per day) are lower compared to US.

- Smaller cars

Differences in the policy between US and Denmark

- The gasoline prices in Denmark are high (1012DKK per litre) compared to US (about 3-4 USD per gallon i.e. approximately 4-5 DKK per litre)

- High taxes for gasoline based cars: Due to the high taxes in Denmark, a medium size gasoline based passenger car costs three times more in Denmark than in the US.

- EDVs are subsidized i.e., they have low/no tax (only 25\% VAT) until 2012. If the EDVs will be commercialized then there could be a reduction in the market price and in this case these tax exemptions are likely to be reduced or totally removed.

- The political target is to reach a wind power penetration of $50 \%$ as yearly average before 2030 .

Due to the above reasons the Danish situation can be seen as a sort of a future scenario for many countries which have a policy of increasing wind power penetration in their power system. The policy of passenger transportation can of cause be quite different, but Danish policy improves the possibilities for a fast introduction of EDVs on the Danish market. EDVs were introduced in about year 2000. Because of the limited performance of the available cars and limited focus on environmental issues the introduction failed. 


\section{DANISH ELECTRICITY NETWORK}

As regards to the electricity network, Denmark is divided into two regions namely the Eastern (DK2 East) and Western Denmark (DK1 West). The DK2 East system is interconnected to the Nordel grid while DK1 West is connected to the UCTE system. At present, there is no interconnection between DK2 East and the DK1 West system.

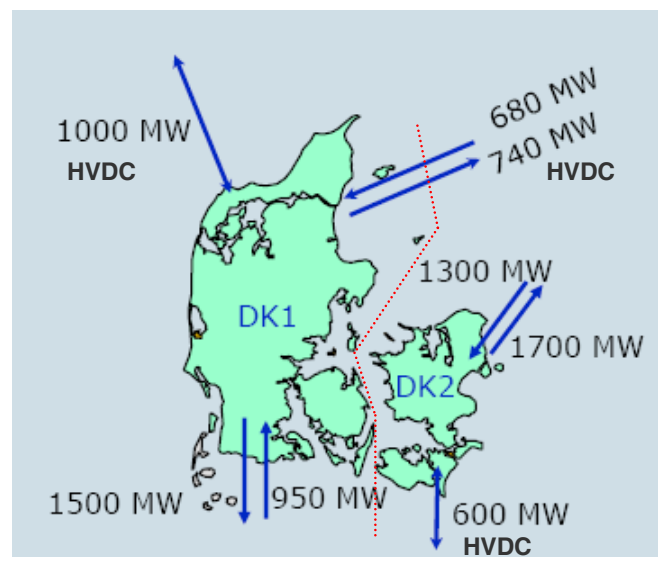

Figure 1: Denmark-Interconnection to the neighbouring countries

The details about the generating units (type, installed capacity and number of units) at different voltage levels are given in Table 1. From this table it is evident that DK1 West only consist of $3.662 \mathrm{GW}$ (11 power plants - i.e. 10 primary units and 1 offshore wind farm connected $>100 \mathrm{kV}$ ) of generation with in the range of central control, while $3.857 \mathrm{GW}$ (4826 generating units) of generation is dispersed generation.

Table1: Generating unit details 2007

\begin{tabular}{|c|c|c|c|}
\hline \multirow[t]{2}{*}{ kV } & \multirow{2}{*}{$\begin{array}{c}\text { Generation } \\
\text { Type }\end{array}$} & DK1 West & DK2 East \\
\hline & & MW & MW \\
\hline 400 & Central CHP & 1488 & 1200 \\
\hline \multirow[t]{2}{*}{$132-150$} & Central CHP & 2014 & 2151 \\
\hline & Wind (off shore) & 160 & 166 \\
\hline \multirow[t]{2}{*}{$50-60$} & Dispersed CHP & 569 & 252 \\
\hline & Wind & 41 & - \\
\hline \multirow[t]{3}{*}{$10-20$} & Dispersed CHP & 991 & 317 \\
\hline & Central CHP & - & 316 \\
\hline & Wind & 1597 & 351 \\
\hline \multirow[t]{2}{*}{0.4} & $\mathrm{CHP}$ & 83 & 68 \\
\hline & Wind & 576 & 194 \\
\hline
\end{tabular}

Furthermore, another interesting observation is that in DK1 West the total installed capacity of wind accounts to about $32 \%$ of the total installed generation capacity. This significant penetration of dispersed generation and wind power are some of the unique features of the DK1
West electricity network and are seldom seen in the present day electricity networks of any other country.

For comparison the maximum and minimum consumption on hourly basis is shown in Table 2. In periods with high wind and cold weather the wind turbines and the dispersed CHP restraint to heat production will cover the total demand of electrical power.

Table 2: Production of electric power details 2007

\begin{tabular}{|c|c|c|}
\hline Production / Consumption & DK1 West & DK2 East \\
\hline Max [MWh/h] & 3767 & 2669 \\
\hline Min [MWh/h] & 1384 & 915 \\
\hline Mean [MWh/h] & 2466 & 1657 \\
\hline
\end{tabular}

The Electricity Market Structure

The Danish electricity market is a liberalized market and a part of the Nord Pool market (Scandinavia). The security of supply is ensured by a non-commercial Transmission System Operator (TSO), Energinet.dk. [2-3] Broadly, the markets can be divided into two types of commercial markets. The markets are mainly about establishing an energy balance per hour. A production plan where demand and generation are in balance hourly will secure the normal frequency in the system as seen over the hour (but not within the hour).

Day ahead (ElSpot) market:

This is the Nord Pool's day ahead auction market where hourly power contracts are traded. About $75 \%$ of all the electricity is traded in this market. The prices on this market will be visible the day before production/consumption takes place. The consumers are seen as large costumers as i.e. larger industry and distribution companies. Normally, private consumers buy electricity from the distribution companies to fixed prices. In future, we expect the hourly prices will be visible for private consumers through intelligent meters. In this way private consumers can plan consumption as charging vehicles according to a price signal.

Ancillary services:

Regulating reserves and ancillary services are purchased by the Transmission System Operator (TSO) from selected central power plants (with must-producecontracts), to ensure stable and reliable operation of the electricity systems. Regulating power in Denmark is usually paid both as a reservation price (Fixed capacity price) and an activation price (Energy price). The types of reserves purchased are seen in Table 3 . 
Table 3. Types and specifications of reserves.

\begin{tabular}{|l|c|c|c|c|c|}
\hline Reserve type & $\begin{array}{c}\text { Min.-Max. } \\
\text { Volume [MW] }\end{array}$ & $\begin{array}{c}\text { Total Capacity } \\
{[\mathrm{MW}]}\end{array}$ & Activation time & $\begin{array}{c}\text { Fixed payment } \\
\text { Typical prices }\end{array}$ & $\begin{array}{c}\text { Energy payment } \\
\text { Typical prices }\end{array}$ \\
\hline Primary & $1-10$ & $+/-50$ & $<30 \mathrm{sec}$. & Fixed capacity & \\
\hline $\begin{array}{l}\text { Regulating aut. } \\
\text { (LFC) }\end{array}$ & $1-25$ & $+/-140$ & $30 \mathrm{sec}-15 \mathrm{~min}$. & $\begin{array}{c}10 \mathrm{MDKK} / \mathrm{Month} \text { for } \\
+/-140 \mathrm{MW}\end{array}$ & $+/-100-125 \mathrm{Dkk} / \mathrm{MWh}$ \\
\hline $\begin{array}{l}\text { Regulating man. } \\
\text { (Tertiary) }\end{array}$ & $10-50$ & $+290 /-310$ & $\begin{array}{c}15 \mathrm{~min}-1 \mathrm{~h} \text { or } \\
\text { several hours }\end{array}$ & $\begin{array}{c}25 \mathrm{k} \text { DKK } / \mathrm{MW} / \\
\text { Month }\end{array}$ & $\begin{array}{c}250 \mathrm{DKK} / \mathrm{MWh} \text { for up regulating } \\
450 \mathrm{DKK} / \mathrm{MWh} \text { for down regulation }\end{array}$ \\
\hline Black start & & 40 & & $15 \mathrm{M} \mathrm{DKK}$ & \\
\hline
\end{tabular}

Min-Max volume is the required range for each agreement on providing reserves

This figure is simplified because DK is divided in two physical supply areas (West and East).

1 DKK is equivalent to about 0.2 USD (At the beginning of 2008)

The EDV's are not expected to participate in primary reserve service because of a rather slow V2G communication and activation system. On the other hand, primary reserve requirements could be met by a local fast responding frequency measuring system [4].

Similar, EDV's are not expected to provide black start capability. This requires a good and fast communication and coordination between the EDV owner and the system operator, which is seen unnecessarily complicated compared to other solutions.

\section{EDV'S IN A DAY AHEAD MARKET}

The day ahead market for electricity is one of the world's most volatile markets, special in case of high wind penetration as in Denmark. In case of surplus of wind power the prices can be as low as zero (more than 80 hours, DK1 West in 2007). In the other end of the scale, the price increased in a single hour up to more than 7000 DDK/MWh (Grid problems, low wind, and high load).

In a market with visible prices for the vehicle owners it could be obvious to handle the cars as flexible loads. Very simple it could be controlled just by using a time switch for charging during night time (8 hours: $22: 00-$ 6:00) Typical we will expect the low prices during the night time and the extreme high prices during the high load period in daytime. The extreme prices mentioned above are following these thumb rules. However, the vehicle owner has a limited battery and a demand of power for daily transportation. The battery capacity is too small for charging only during the extreme price periods. A recommended behaviour for the vehicle owner is to plug-in the car when possible and letting the charging control system charge on daily basis when the price is economically attractive.

For a simplified study the hourly 2007 prices from the two market areas are used. Because of a higher penetration of wind power in the DK1 West, the prices are more volatile compared to the eastern area. In figure 2 , the hourly prices are sorted from night time and daytime - duration curves. As seen the number of extreme prices are so limited that the daily charging cannot be based on that. Instead more "normal" prices can be expected as the price condition for charging. During more than $66 \%$ of the night hours the price level is between 140 and $210 \mathrm{DKK} / \mathrm{MWh}$. Equivalent, we see during daytime close to $90 \%$ of the price level is between 135 and 400 DKK/MWh. By using a simple time switch for charging control the owner can save about $100 \mathrm{DDK} / \mathrm{MWh}$, corresponding to less than 1 DDK per day for a typical Danish driving pattern of 40 $\mathrm{km}$ per day (4-8 kWh).

Fig. 2 EISpot Market. Duration curves showing hourly prices

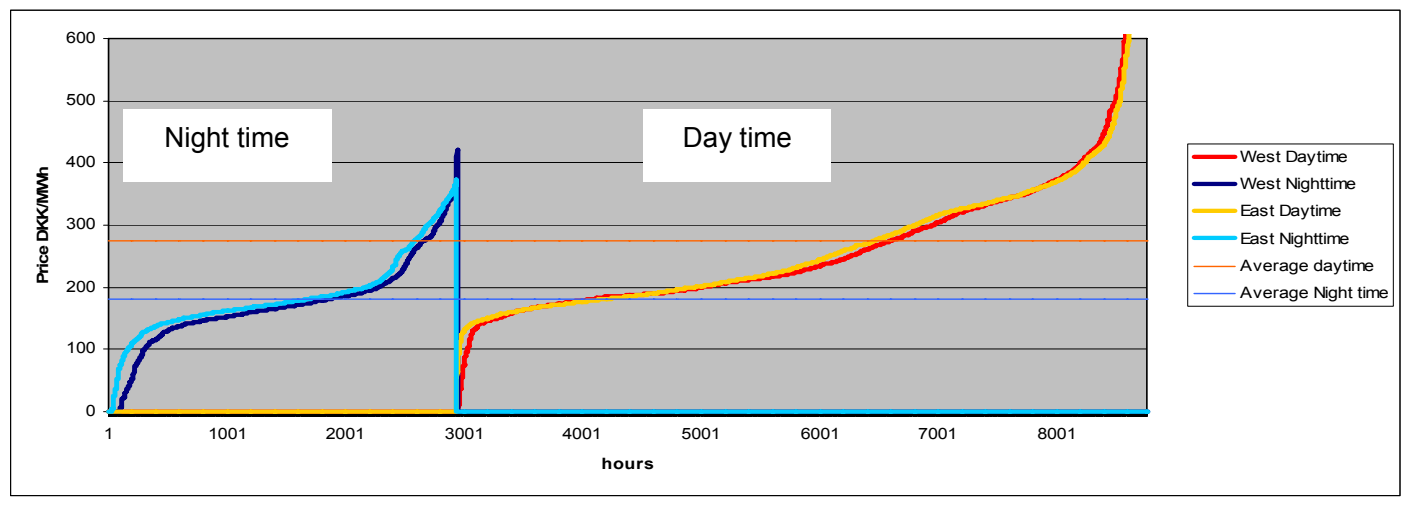


In a future scenario of wind penetration with up to $50 \%$ in average can we follow the trend from east to west, i.e. from a wind penetration of about $16 \%$ in east to about $23 \%$ in west. The periods with extreme prices are expected to increase while only a minor increase is seen on the "normal" price level.

Similar situations will be seen for a V2G system. Controlled by a price signal, power charged in the night and discharged during day time causing an energy loss of $15 \%$ will be compensated by $150-200 \mathrm{DDK} / \mathrm{MWh}$. Higher price differences are only met in rather few hours per year.

Generally, in the day ahead market it is a question if even a simple and cheap control solution i.e. a time switch will be a profitable investment. In other electricity markets the durations curve can be quit different e.g. the German market, which could show possibilities for a profitable charging system based on a day a head price signal.

\section{EDV'S AS PROVIDER OF ANCILLARY SERVICES}

As seen in Table 3 ancillary services are provided under specified limitations and the payment is divided in two parts, a fixed payment for availability and a flexible price for activation (Energy). These requirements are by no means simple to reach using a cluster of EDV's. Different systems are under development for handling a cluster of vehicles acting as one unity fulfilling the requirements of providing ancillary services. Independent of the technical solution the market could be reach through a retailer who aggregates many EDV capacities. On the other hand the payment is good for the availability which has the consequence for the owner to be plugged in when possible. The second part, the energy price, will vary according to a market similar to the day ahead market: ElSpot. Figure 3 shows the up/down regulation price variation in DK-West during the year 2007. From the figure it may be seen that the TSO pays up to an extremely high price (max. 7026 DKK/MWh) for providing up regulation service. In 2007 for down regulation (reduction of generation) the TSO had to pay a price up to $1400 \mathrm{DKK} / \mathrm{MWh}$ (all the negative spikes seen in fig 3). The TSO had to pay for consuming the surplus of generation, typically wind power. Instead of up/down regulation of power plants V2G-vehicles could discharge/charge. As earlier mentioned a V2G system cannot be based on the extreme prices. In mean the up-regulating price was $274 \mathrm{DKK} / \mathrm{MWh}$.

Figure 3: Price for Up / Down Regulation (DK1 West 2007)

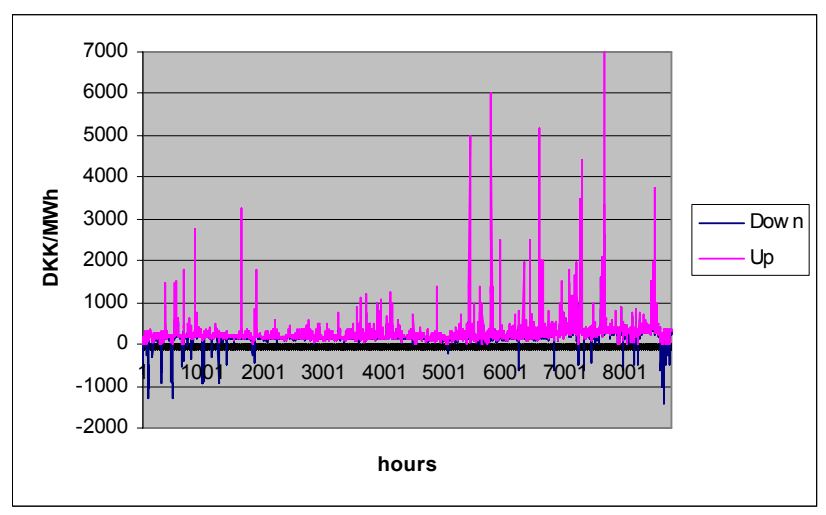

In Table 4 there is given an estimate of the fixed payment the EDV owner receives for providing the battery (availability payment only) for the LFC and manual reserve ancillary services for different maximum charging/discharging power capacity. The costs presented in Table 4 are only for availability and it may be seen that the payment is higher for providing LFC as compared to providing manual reserves.

Furthermore, it must be noted that the LFC reserves are required typically for 15 mins while the manual reserves could be needed from 15 mins to about an hour. In order to estimate the total payment an EDV owner is likely to receive the energy prices also need to be calculated. The energy prices depend on not only the market hourly prices but also on the EDV availability (which includes the EDV owner's preference, state of charge, and availability of the infrastructure) and the system constraints (energy requirements and place if there are congestions). Here, the energy prices are calculated using the average prices stated in Table 3 under assumption of an EDV availability.

Table 4 Availability payment made to the EDV owner for rendering ancillary service

\begin{tabular}{|c|c|c|c|c|c|}
\hline $\begin{array}{c}\text { Max. } \\
\text { energy } \\
\text { available } \\
\text { (EDV } \\
\text { battery } \\
\text { constraint) }\end{array}$ & $\begin{array}{c}\text { Max. } \\
\text { Power } \\
\text { (chargerl } \\
\text { discharger } \\
\text { constraint) }\end{array}$ & \multicolumn{2}{|c|}{ Max. energy that can be provided (kWh) } & \multicolumn{2}{c|}{$\begin{array}{c}\text { Availability payment made to } \\
\text { EDV owner for grid services }\end{array}$} \\
\cline { 3 - 6 } & & LFC & Manual reserve & $\begin{array}{c}\text { LFC } \\
\text { (DKK) }\end{array}$ & $\begin{array}{c}\text { Manual reserve } \\
\text { (DKK) }\end{array}$ \\
\hline $5 \mathrm{kWh}$ & $2 \mathrm{~kW}$ & $2 \mathrm{~kW} \times 15 \mathrm{~min}=0.5 \mathrm{kWh}$ & $2 \mathrm{~kW} \times 1 \mathrm{~h}=2 \mathrm{kWh}$ & 1370 & 480 \\
\hline $5 \mathrm{kWh}$ & $20 \mathrm{~kW}$ & $20 \mathrm{~kW} \times 15 \mathrm{~min}=5 \mathrm{kWh}$ & $5 \mathrm{kWh}$ & 13700 & 4800 \\
\hline $20 \mathrm{kWh}$ & $20 \mathrm{~kW}$ & $20 \mathrm{~kW} \times 15 \mathrm{~min}=5 \mathrm{kWh}$ & $20 \mathrm{kWh}$ & 13700 & 4800 \\
\hline
\end{tabular}


Table 5: Payment the battery owner might get for rendering LFC service in the Distributed charging V2G architecture

\begin{tabular}{|c|c|c|c|c|}
\hline \multicolumn{2}{|c|}{ LFC capacity (assuming maximum power) } & \multicolumn{3}{|c|}{ Likely annual returns (DKK) } \\
\hline Power & Energy/hour & Availability & Energy & Total \\
\hline $2 \mathrm{~kW}$ & $2 \times 15 \mathrm{~min}=0.5 \mathrm{kWh}$ & $1.37 \mathrm{kDKK}$ & $70 \mathrm{DKK}$ & $1.44 \mathrm{kDKK}$ \\
\hline $20 \mathrm{~kW}$ & $20 \times 15 \mathrm{~min}=5 \mathrm{kWh}$ & $13.7 \mathrm{kDKK}$ & $700 \mathrm{DKK}$ & $14.4 \mathrm{kDKK}$ \\
\hline
\end{tabular}

Table 6: Payment the battery owner might get for rendering Manual reserve service in the Distributed charging V2G architecture

\begin{tabular}{|c|c|c|c|c|c|c|}
\hline \multicolumn{2}{|c|}{ Manual reserve capacity } & \multicolumn{5}{c|}{ Likely annual returns } \\
\hline Power & Energy/hour & $\begin{array}{c}\text { Availability } \\
\text { DKK }\end{array}$ & $\begin{array}{c}\text { Energy } \\
\text { DKK }\end{array}$ & $\begin{array}{c}\text { Total (Up } \\
\text { regulation) }\end{array}$ & $\begin{array}{c}\text { Energy } \\
\text { DKK }\end{array}$ & $\begin{array}{c}\text { Total (Down } \\
\text { regulation) }\end{array}$ \\
\hline $2 \mathrm{~kW}$ & $2 \mathrm{kWh}$ & 480 & 1050 & $1.53 \mathrm{kDKK}$ & 28 & $0.508 \mathrm{kDKK}$ \\
\hline $20 \mathrm{~kW}$ & $5 \mathrm{kWh}$ & 4800 & 2628 & $7.43 \mathrm{kDKK}$ & 70 & $4.87 \mathrm{kDKK}$ \\
\hline $20 \mathrm{~kW}$ & $20 \mathrm{kWh}$ & 4800 & 10500 & $15.3 \mathrm{kDKK}$ & 280 & $10.78 \mathrm{kDKK}$ \\
\hline
\end{tabular}

Table 5 and Table 6 give the total annual payment (availability \& energy) an EDV owner is likely to receive for providing LFC and Manual reserve services respectively. Comparing the two tables, it may be seen that the EDV owner could receive a significant payment of rendering either of the two services.

Furthermore, for the same energy capacity, the earnings an EDV owner obtains by providing the LFC is much higher than the one earned by providing manual reserves. It is because of the high availability price paid by the TSO for providing LFC (although the energy price is higher for providing Manual reserve as compared to LFC).

In addition to the payments received of providing upregulation service, the EDV owner can at certain times receive payment from the electrical utility for charging the EDV as seen from Figure 3 (Down regulating, i.e. consumption of surplus).

The payments made to the EDV owner for providing down regulation service are calculated assuming that:

i) the EDVs provide down regulation service only when the TSO pays

ii) the frequency such payments were made in 2007 (during the year 2007 the TSO paid for down regulation in less than $5 \%$ of the hours). Even though, the percentage of time when the EDV owner encounters such a situation is small, it may be seen that the returns are quiet high. This is because of the high price paid for availability and also because during such hours the TSO pays high energy prices for increasing the consumption. However, as mentioned earlier these situations did not occur very often in 2007, but in future it is anticipated that when $50 \%$ of the electricity demand is met by wind power the number of hours when the TSO has to pay a high price to down regulate could increase. iii) The number of vehicle providing the service is limited, only to cover a part of needed ancillary services.

iv) The introduction of providing ancillary services will not influence the prices,

The estimated prices require only a limited number of EDV's because the provided ancillary services can be reached through a limited number of EDVs depending on the power and energy capability of the cars. If less than $10 \%$ of the Danish cars were EV's with V2G capabilities these could cover the demand of ancillary services.

\section{CONCLUSION}

Based on the experience and market data from Denmark having a power system with a wind penetration higher than $20 \%$, studies are discussed which introduce a V2G-system in the power system market. No doubt, the EDV's will play an interesting role in a future power system caused by the battery power storage provided in the power system. First of all the EDV's is a significant new power consumer, second as a possible provider of energy storage, i.e. V2G. An intelligent architecture is needed for control of charging and V2G system services. Studies show there are only small economical benefits using the car as a flexible load in the day ahead market. If intelligent systems for providing ancillary services are developed, significant payment can be expected from the TSO. However, these services can be reached by a considerably but limited number of vehicles. New providers of ancillary services will increase the competition in a profitably market causing expectations to a decrease in prices. 


\section{PERSPECTIVES}

The perspectives of research for development of a grid architecture prepared to handle a substantial amount of EDV's in Denmark is:

- a development of system solutions and technologies for EDVs which enable a sustainable, economic and reliable energy system where the properties of EDVs are utilised in a power system with substantial renewable energy.

- to prepare and provide a technical platform for Danish demonstrations of EDVs with emphasis on the power system integration aspects.

- to develop standard system solutions for EDVs, which are applicable globally, by utilising the substantial Danish knowledge within distributed energy resources and operation of energy systems with high wind power penetration.

\section{REFERENCES}

[1] Y. Chen, Z. Xu, J. Østergaard, Frequency Analysis for Planned Islanding Operation in the Danish Distribution System - Bornholm, 43rd International Universities Power Engineering Conference, Padova, Italy, 2008"

[2] Nordel (Organisation for the Nordic Transmission System Operators): http://www.nordel.org/Content/Default.asp

[3] Nord Pool Electricity Market: http://www.nordpoolspot.com/

[4] Z. Xu, J. Østergaard, M. Togeby; C. Marcus-Møller, Design and Modelling of Thermostatically Controlled Loads as Frequency Controlled Reserve, IEEE PES General Meeting, Tampa, Florida, 2007

[5] Divya K. Chandrashekhara et.al.: Vehicle to Grid (V2G) in Denmark - Feasibility Study, DTU, June 2008 (internal report) 